\title{
Seroprevalence of Coxiella burnetii ( $Q$ fever) in Cows and Buffaloes in Egypt
}

\author{
Hassan F. M. Mo'awad ${ }^{1}$, Mona M Sobhy ${ }^{1}$, Tamer F. Ismail ${ }^{2}$ and Mona El-Enbaawy ${ }^{3 *}$ \\ ${ }^{1}$ Department of Reproductive Diseases, Animal Reproduction Research Institute, Agricultural Research Center, Giza, \\ Egypt; ${ }^{2}$ Department of Veterinary Hygiene and Management, Faculty of Veterinary Medicine, Cairo University, Giza, \\ Egypt; ${ }^{3}$ Department of Microbiology, Faculty of Veterinary Medicine, Cairo University, Giza, Egypt \\ *Corresponding author: dr_mona_1@ @hotmail.com
}

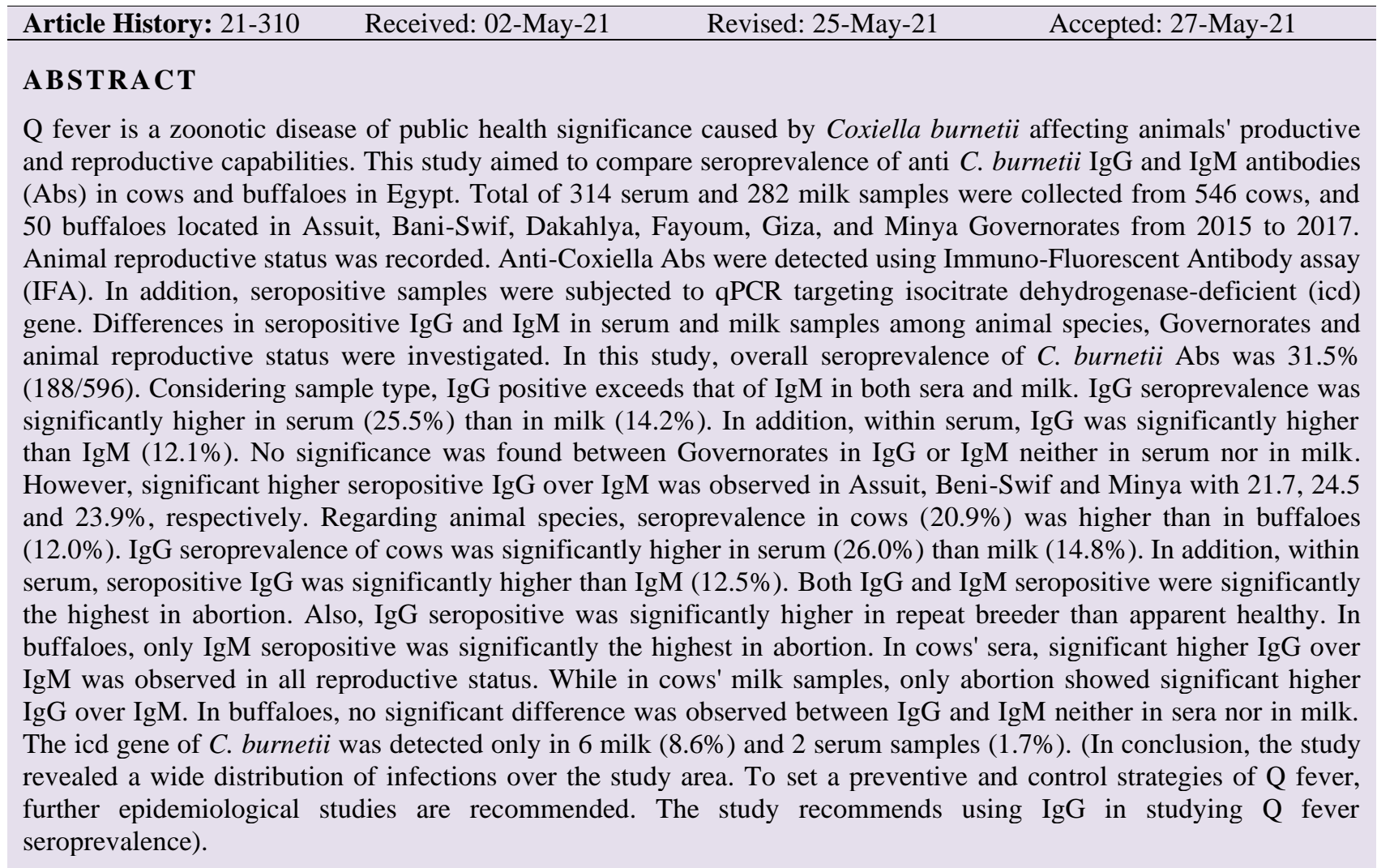

Key words: Coxiella burnetii, IFA, IgG, IgM, Cows, Buffaloes, Egypt.

\section{INTRODUCTION}

Q fever is a zoonotic disease caused by C. burnetii, a Gram negative obligate intracellular bacterium (Van Leuken et al. 2016; Sherry et al. 2019; Peter 2020). Coxiellosis affects various hosts including humans, ruminants, pets, cats, dogs, and wildlife may also serve as reservoirs for C. burnetii (Eldin et al. 2017). C. burnetii Phase I is highly infectious and can be isolated from human or animal (Gürtler et al. 2014). The infectious agent may be shed in milk, urine, and feces and found in high concentration in placenta and birth fluid (Eldin et al.
2017). Bacterial reservoirs in herds were capable of transmitting and maintaining infection in herds (Angen et al. 2011). Clinical signs of coxiellosis in animals vary, usually asymptomatic with subclinical presentation except in ruminants, where it is usually characterized by reproductive problems such as abortion, premature birth, stillbirth, weak offspring, endometritis and infertility (Agerholm 2013; Carbonero et al. 2015; OIE 2015; Chochlakis et al. 2018). Q fever is a neglected zoonosis in Egypt, and limited data on coxiellosis in human, and animals are available (Abbass et al. 2020). The accurate diagnosis of coxiellosis in animals is of great importance

Cite This Article as: Mo'awad HFM, Sobhy MM, Ismail TF and El-Enbaawy M, 2022. Seroprevelance of Coxiella burnetii (Q fever) in cows and buffaloes in Egypt. International Journal of Veterinary Science 11(1): 16-22. https://doi.org/10.47278/journal.ijvs/2021.068 
to identify the infected flocks and to determine the public health significance of the disease in human (OIE 2016). $C$. burnetii does not grow using standard routine laboratory culture methods, so specific direct, and indirect diagnostic techniques have been used in diagnosis for detection of anti-Coxiella Abs and DNA (Eldin et al. 2017). IFA, ELISA and CFT are equal in diagnosis of acute Q fever but more $\operatorname{IgG}$ and $\operatorname{IgM}$ antibodies were detected by IFA than ELISA or CFT which make IFA more suitable for screening programs (Wegdam-Blans et al. 2012). This study aimed to compare the seroprevalence of anti $C$. burnetii Abs among sample types, Governorates and animal reproductive status in cows and buffalos in Egypt.

\section{MATERIALS AND METHODS}

\section{Animal Ethics}

All animal related procedures in the study were approved by Animal Reproduction Research Institute' research committee. The study was applied on adult animals healthy or suffering from reproductive problems.

\section{Samples Collection}

Total of 314 blood and 282 milk samples were collected from 546 cows and 50 buffaloes located in Assuit, Bani-Swif, Dakahlya, Fayoum, Giza, and Minya governorates during January 2015 to December 2017. Briefly, $5 \mathrm{ml}$ blood or milk were collected aseptically into plain vacationers (Vaccutest Kima, Italy), samples were transported on ice to the laboratory. Blood samples were centrifuged at 3000rpm for $5 \mathrm{~min}$ (Heal Force, Shanghai Lishen Scientific Equipment Co. Ltd. China), collected serum was pipetted into $1.5 \mathrm{ml}$ Eppendorf tubes (Eppendorf, Germany) and stored at $-20^{\circ} \mathrm{C}$ until tested. Milk samples were centrifuged at $10000 \mathrm{rpm}$ at $10^{\circ} \mathrm{C}$ for $10 \mathrm{~min}$, separated milk or serum was collected in $1.5 \mathrm{ml}$ Eppendorf tubes. Reproductive status and geographical distribution data were recorded.

\section{Serological Investigation}

Serum and milk samples were subjected to IFA, using commercially provided kits Coxiella burnetii II IFA IgG or IgM (Vircell S.L., Spain) according to manufacturing instructions. Sera and milk samples were tested for IgG and IgM Abs against $C$. burnetii phase II using slides coated with $C$. burnetii antigen phase II. The reaction was considered positive when apple green fluorescence of coco-bacillary morphology was observed (Vaidya et al. 2008; OIE 2016).

\section{Molecular Investigation}

Samples showed seropositive for either IgG or IgM were subjected to quantitative real-time PCR targeting isocitrate icd gene (Maurin and Raoult 1999) Table 1. DNA extraction using DNA Miniprep Quick and Dirty Alkaline Lysis (Untergasser Lab, Germany). DNA from milk and sera samples was isolated using High Pure PCR Template Preparation Kit (Roche, Germany) according to the manufacturer's instructions. PCR protocol consists of decontamination one cycle for $2 \mathrm{~min}$ at $50^{\circ} \mathrm{C}$, initial denaturation one cycle for $10 \mathrm{~min}$ at $95^{\circ} \mathrm{C}$, and 45 cycles of denaturation for $15 \mathrm{~s}$ at $95^{\circ} \mathrm{C}$ and annealing-elongation for $30 \mathrm{~s}$ at $60^{\circ} \mathrm{C}$ according to Kit's manufacturer (Roche Diagnostics, Germany).

\section{Statistical Analysis}

Analyses were performed using SPSS software ${ }^{\circledR}$ version 20 (IBM Corp, USA). The Chi-square or Fisher's exact test was used to determine differences in seropositive of IgG and IgM in serum and milk samples among governorates, species and animal reproductive status $(\mathrm{P}<0.05)$ were considered significant.

\section{RESULTS}

\section{Serological Investigation}

Out of 596 examined samples, $188(31.5 \%)$ were seropositive; $120(20.1 \%)$ for $\operatorname{IgG}$ (80 from serum and 40 from milk) and 68 (11.4\%) for IgM (38 from serum and 30 from milk). Percentage of positive IgG was significantly higher in serum $25.5 \%$ than in milk $14.2 \%$. On the other side, no significant difference was observed between positive IgM in serum and milk; 12.1 and $10.6 \%$, respectively. Within 314 samples of serum, IgG positive $(25.5 \%)$ was significantly higher than IgM positive $(12.1 \%)$. Within milk 282 samples, non-significant difference was observed between positive $\operatorname{IgG}$ and $\operatorname{IgM}$ 14.2 and $10.6 \%$, respectively.

Table 2 shows anti Coxiella IgG \& IgM in sera and milk samples in different governorates. All six governorates showed seropositive in sera and milk samples. In sera, the highest IgG seroprevalence was detected in Beni-swif (27.9\%), Minya (26.7\%), then Assuit, Fayoum, Giza, and Dakahlya with 25, 25, 24.4 and $23.8 \%$, respectivly. For serum IgM, the highest seroprevalence of $14.3 \%$ was detected in Fayoum and Dakahlya followed by Giza (13.4\%) then by Assuit, Beniswif and Minya with $11.1,10.3$ and $6.7 \%$, respectivly. For milk IgG, the highest seroprevalence (18.8\%) was detected in Minya followed by $16.7 \%$ in Beni-swif and Assuit then Giza, Dakahlya and Fayoum with 16, 13.3 and $12.1 \%$, respectivly. For milk $\operatorname{IgM}$, the highest seroprevalence $(13.3 \%)$ was detected in Dakahlya followed by Giza (12\%) then Fayoum, Assuit, Beni-swif and Minya with 11.4, 8.3, 6.7 and 6.3\%, respectivly. No significance was found between Governorates in IgG or IgM either in sera or in milk. In general, the total positive IgG exceed that of total IgM within all governorates. However, significant higher IgG seropositive percentages over IgM was observed only in Assuit, Beni-swif and Minya with $21.7,24.5$ and $23.9 \%$, respectively.

Fig. 1 displays anti Coxiella Abs in serum and milk samples of buffalo and cow. In buffaloes, total anti Coxiella Abs for sera and milk was 22.2 and $15.7 \%$, respectively. No significant difference was observed between positive IgG or IgM in serum and milk. In cows, total anti Coxiella Abs for serum and milk was 38.5 and $26.0 \%$, respectively. IgG was significantly higher in serum $(26 \%)$ than in milk $(14.8 \%)$. In addition, within cows' serum, seropositive IgG $(26 \%)$ was significantly higher than seropositive IgM (12.5\%). No significant difference was detected between positive $\operatorname{IgM}$ in serum and milk samples.

Table 3 shows seroprevalence of anti-Coxiella Abs in different reproductive status of buffaloes and cows. For buffaloes, no significant difference was observed in IgG seroprevalence between different reproductive status group. While in cows, IgG seropositive was significantly 
Int J Vet Sci, 2022, 11(1): 16-22.

Table 1: PCR protocol: Coxiella burnetii q PCR

\begin{tabular}{|c|c|c|c|c|c|}
\hline \multirow[t]{2}{*}{ Reagents } & C. burnetii icd gene & & \multirow[b]{2}{*}{ End conc. } & \multirow[b]{2}{*}{$\mu \mathrm{l} / 1 \mathrm{x}$} & 38Wells \\
\hline & 5'-3' Sequence & & & & $42 \mathrm{x}$ \\
\hline Water & & & & 7.5 & 315 \\
\hline Master mix & Maxima probe qPCR & $2 \mathrm{X}$ & $1 \mathrm{X}$ & 12.5 & 525 \\
\hline Icd $439 \mathrm{~F}$ & CGTTATTTTACGGGTGTGCCA & $7.5 \mu \mathrm{M}$ & $300 \mathrm{nM}$ & 1 & 42 \\
\hline Icd $439 \mathrm{R}$ & CAGAATTTTCGCGGAAAATCA & $7.5 \mu \mathrm{M}$ & $300 \mathrm{nM}$ & 1 & 42 \\
\hline Icd- 464 TMCoxbur & FAM-CATATTCACCTTTTCAGGCGTTTTGACCGT & $2.5 \mu \mathrm{M}$ & $100 \mathrm{nM}$ & 1 & 42 \\
\hline & & Master mix & & 23 & 966 \\
\hline & & Template & & 2 & \\
\hline & & Total & & 25 & \\
\hline
\end{tabular}

Table 2: Anti Coxiella IgG and IgM in sera and milk samples of different Governorates

\begin{tabular}{|c|c|c|c|c|c|c|c|}
\hline \multirow[t]{2}{*}{ Governorate } & & \multicolumn{2}{|c|}{ Serum } & \multicolumn{2}{|c|}{ Milk } & \multirow{2}{*}{$\begin{array}{c}\text { Total } \\
\text { IgG }\end{array}$} & \multirow{2}{*}{$\begin{array}{l}\text { Total } \\
\text { IgM } \\
\end{array}$} \\
\hline & & $\mathrm{IgG}$ & IgM & $\mathrm{IgG}$ & $\operatorname{IgM}$ & & \\
\hline \multirow{2}{*}{ Assuit } & Count/Total & $9 / 36$ & $4 / 36$ & $4 / 24$ & $2 / 24$ & $13 / 60$ & $6 / 60$ \\
\hline & $\%$ within governorate & (25) & (11.1) & $(16.7)$ & (8.3) & $(21.7)^{*}$ & (10) \\
\hline \multirow{2}{*}{ Beni-swif } & Count/Total & $19 / 68$ & $7 / 68$ & $5 / 30$ & $2 / 30$ & $24 / 98$ & 9/98 \\
\hline & $\%$ within governorate & $(27.9)$ & $(10.3)$ & $(16.7)$ & (6.7) & $(24.5)^{*}$ & (10) \\
\hline \multirow{2}{*}{ Fayoum } & Count/Total & $14 / 56$ & $8 / 56$ & $16 / 132$ & $15 / 132$ & $30 / 198$ & $23 / 198$ \\
\hline & $\%$ within governorate & (25) & (14.3) & $(12.1)$ & $(11.4)$ & (15.2) & $(11.6)$ \\
\hline \multirow{2}{*}{ Giza } & Count/Total & $20 / 82$ & $11 / 82$ & $8 / 50$ & $6 / 50$ & $28 / 132$ & $17 / 132$ \\
\hline & $\%$ within governorate & $(24.4)$ & (13.4) & (16) & (12) & $(21.2)$ & $(12.9)$ \\
\hline \multirow{2}{*}{ Dakahlya } & Count/Total & $10 / 42$ & $6 / 42$ & $4 / 30$ & $4 / 30$ & $14 / 72$ & $10 / 72$ \\
\hline & $\%$ within governorate & $(23.8)$ & (14.3) & $(13.3)$ & $(13.3)$ & (19.4) & $(13.9)$ \\
\hline \multirow{2}{*}{ Minya } & Count/Total & $8 / 30$ & $2 / 30$ & $3 / 16$ & $1 / 16$ & $11 / 46$ & $3 / 46$ \\
\hline & $\%$ within governorate & (26.7) & $(6.7)$ & $(18.8)$ & (6.3) & $(23.9)^{*}$ & (6.5) \\
\hline
\end{tabular}

* Indicates significance within row at $\mathrm{P}<0.05$. Values in parenthesis indicate $\%$.

Table 3: Seroprevalence of anti Coxiella $\operatorname{IgG}$ and $\operatorname{IgM}$ in different reproductive status of buffaloes and cows

\begin{tabular}{llcccc}
\hline \multirow{2}{*}{ Reproductive Status } & \multicolumn{2}{c}{ Buffaloes } & \multicolumn{3}{c}{ Cows } \\
\cline { 3 - 6 } & & $\operatorname{IgG}$ & $\operatorname{IgM}$ & $\operatorname{Ig}$ & \\
\hline \multirow{2}{*}{ Abortion } & Count/Total & $1 / 3$ & $2 / 3$ & $13 / 20$ & $6 / 20$ \\
Repeat & \% within status & $(33.3)$ & $(66.7)^{\mathrm{a}}$ & $(6) 5^{\mathrm{a}}$ & $(30)^{\mathrm{a}}$ \\
Breeder & Count/Total & $1 / 8$ & $0 / 8$ & $53 / 227$ & $26 / 227$ \\
Apparent & \% within status & $(12.5)$ & $(0)^{\mathrm{b}}$ & $(23.3)^{\mathrm{b}}$ & $(11.5)^{\mathrm{b}}$ \\
Healthy & Count/Total & $4 / 39$ & $1 / 39$ & $48 / 229$ & $33 / 229$ \\
\hline
\end{tabular}

Different super scripts indicate significance within column of species at $\mathrm{P}<0.05$.

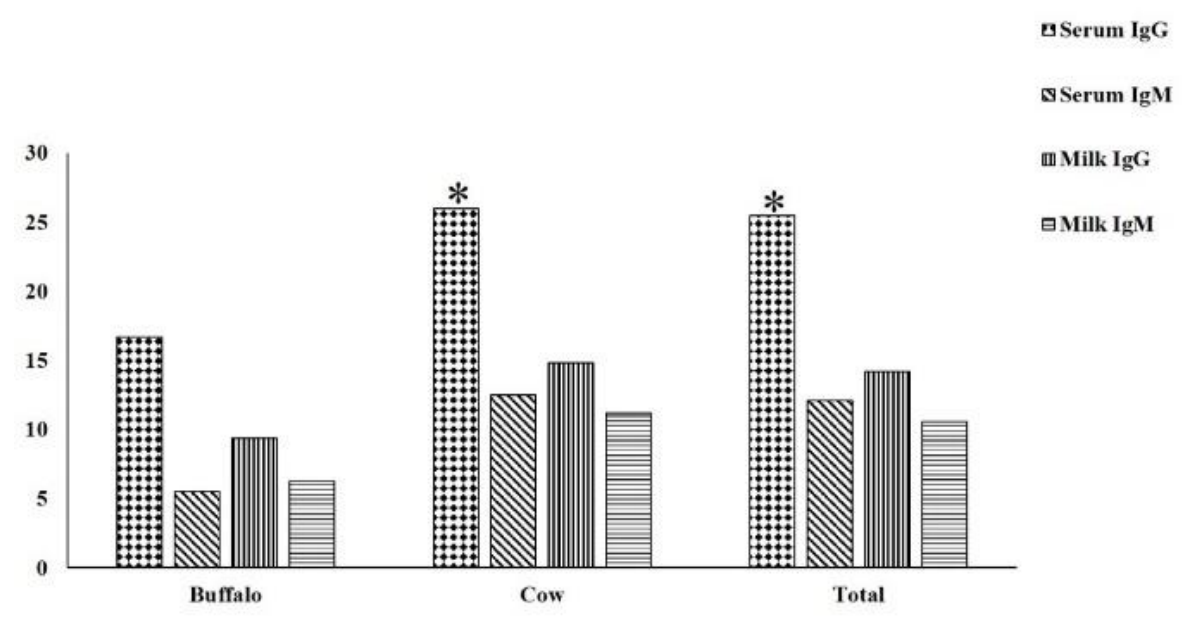

Fig. 1: Anti Coxiella IgG \& IgM in sera and milk samples of buffalo and cow. *Indicates significance at $\mathrm{P}<0.05$.

Table 4 and 5 present reproductive status $\mathrm{IgG}$ and IgM crosstabulation in serum and milk samples of buffalos and cows. For buffaloes' reproductive status, no significance was observed between seropositive IgG and IgM in milk or serum samples. For cows' reproductive status, in serum samples, significant higher seropositive IgG over $\operatorname{IgM}$ was observed in abortion, apparently healthy and repeat breeder; 72.7, 21.5 and $26 \%$, respectively. In milk samples, only abortion showed significant higher seropositive $\operatorname{IgG}(55.6 \%)$ over $\operatorname{IgM}$ $(33.3 \%)$.

\section{Molecular Investigation}

Photo 1, out of 188 (70 milk and 118 serum) seropositive samples, icd gene of $C$. burnetii was detected only in 6 milk $(8.6 \%)$ and 2 sera samples $(1.7 \%)$. 
Int J Vet Sci, 2022, 11(1): 16-22.

Amplification Plots

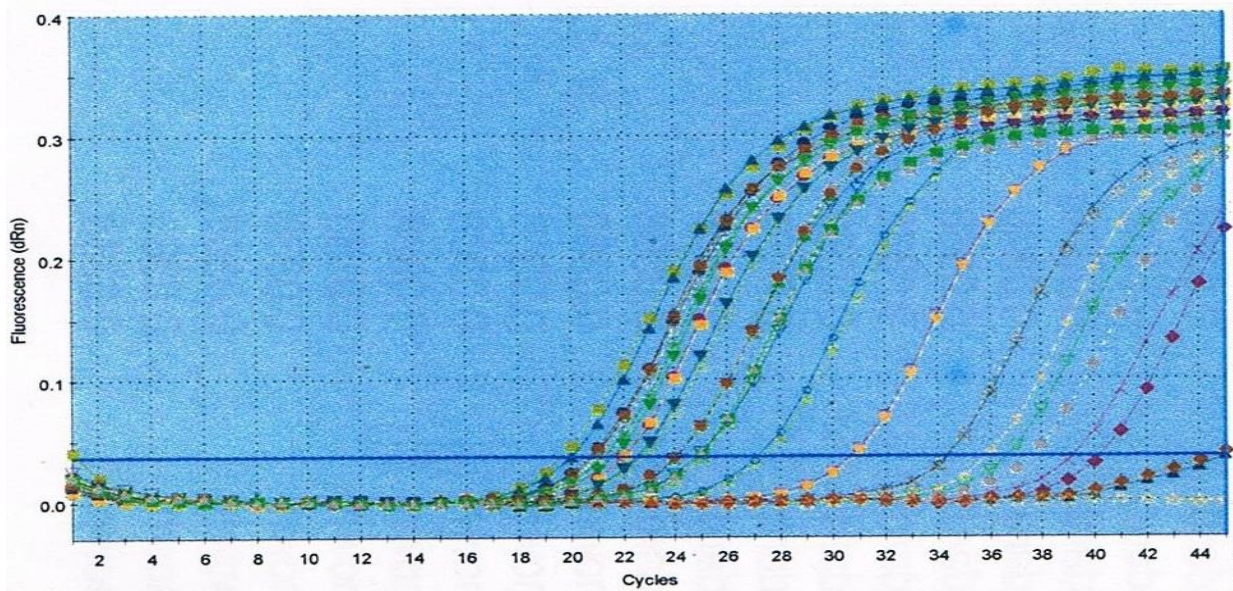

Fig. 2: Q PCR detection of $C$. burnetii icd gene at seropositive milk and sera samles in cow and buffale

Table 4: $\operatorname{IgG}$ and $\operatorname{IgM}$ crosstabulation in serum samples in relation to reproductive status

\begin{tabular}{|c|c|c|c|c|c|c|c|}
\hline & & $\Delta \mathrm{ni}$ & pecies & & & & Totol \\
\hline & & AllI & pectes & & Negative & Positive & 10tal \\
\hline Buffalo & Apparent & $\operatorname{IgG}$ & Negative & Count & 14 & 1 & 15 \\
\hline & Healthy & & & $\%$ of Total & (77.8) & (5.6) & (83.3) \\
\hline & & & Positive & Count & 3 & 0 & 3 \\
\hline & & & & $\%$ of Total & (16.7) & (0) & (16.7) \\
\hline & & & Total & Count & 17 & 1 & 18 \\
\hline Cow & Abortion & $\mathrm{IgG}$ & Negative & Count & 0 & 3 & 3 \\
\hline & & & & $\%$ of Total & (0) & $(27.3)$ & (27.3) \\
\hline & & & Positive & Count & 8 & 0 & 8 \\
\hline & & & & $\%$ of Total & $(72.7)^{*}$ & (0) & (72.7) \\
\hline & & & Total & Count & 8 & 3 & 11 \\
\hline & Apparent & $\mathrm{IgG}$ & Negative & Count & 92 & 14 & 106 \\
\hline & Healthy & & & $\%$ of Total & $(68.1)$ & (10.4) & (78.5) \\
\hline & & & Positive & Count & 29 & 0 & 29 \\
\hline & & & & $\%$ of Total & $(21.5)^{*}$ & (0) & $(21.5)$ \\
\hline & & & Total & Count & 121 & 14 & 135 \\
\hline & Repeat & $\mathrm{IgG}$ & Negative & Count & 91 & 19 & 110 \\
\hline & Breeder & & & $\%$ of Total & $(60.7)$ & (12.7) & (73.3) \\
\hline & & & Positive & Count & 39 & 1 & 40 \\
\hline & & & & $\%$ of Total & $(26)^{*}$ & (0.7) & (26.7) \\
\hline & & & Total & Count & 130 & 20 & 150 \\
\hline
\end{tabular}

* Indicates significance at $\mathrm{p}<0.05$

Table 5: $\operatorname{IgG}$ and IgM crosstabulation in milk samples in relation to reproductive status

\begin{tabular}{|c|c|c|c|c|c|c|c|}
\hline & & & & & & & \\
\hline & & Anim & ecies & & Negative & Positive & Total \\
\hline Buffalo & Abortion & $\mathrm{IgG}$ & Negative & Count & 0 & 2 & 2 \\
\hline & & & & $\%$ of Total & (0) & $(66.7)$ & $(66.7)$ \\
\hline & & & Positive & Count & 1 & 0 & 1 \\
\hline & & & & $\%$ of Total & (33.3) & (0) & (33.3) \\
\hline & & Total & & Count & 1 & 2 & 3 \\
\hline Cow & Abortion & $\operatorname{IgG}$ & Negative & Count & 1 & 3 & 4 \\
\hline & & & & $\%$ of Total & (11.1) & (33.3) & (44.4) \\
\hline & & & Positive & Count & 5 & 0 & 5 \\
\hline & & & & $\%$ of Total & $(55.6)^{*}$ & (0) & $(55.6)$ \\
\hline & & Total & & Count & 6 & 3 & 9 \\
\hline & Apparent & $\operatorname{IgG}$ & Negative & Count & 126 & 19 & 145 \\
\hline & Healthy & & & $\%$ of Total & (76.8) & (11.6) & (88.4) \\
\hline & & & Positive & Count & 19 & 0 & 19 \\
\hline & & & & $\%$ of Total & (11.6) & (0) & (11.6) \\
\hline & & Total & & Count & 145 & 19 & 164 \\
\hline & Repeat & $\mathrm{IgG}$ & Negative & Count & 58 & 6 & 64 \\
\hline & Breeder & & & $\%$ of Total & (75.3) & (7.8) & $(83.1)$ \\
\hline & & & Positive & Count & 13 & 0 & 13 \\
\hline & & & & $\%$ of Total & (16.9) & (0) & (16.9) \\
\hline & & Total & & Count & 71 & 6 & 77 \\
\hline
\end{tabular}

* Indicates significance at $\mathrm{P}<0.05$. 


\section{DISCUSSION}

In this study, seroprevalence of $C$. burnetii Abs, in sera and milk samples from buffaloes and cows located in six Egyptian Governorates, was investigated using IFA. IFA test is the most specific and sensitive for phase II and phase I IgG Abs and, to a lesser extent, for the phase II and phase I IgM Abs (Setiyono et al. 2005). Seropositive IgG and IgM among sample type, Governorates, species and reproductive status of animal were studied. In general, positive $\operatorname{IgG}$ exceed that of $\operatorname{IgM}$ in both sera and milk. These results confirm that IgM results provide subsidiary evidence to $\operatorname{IgG}$ titers (CDC 2013). The overall seroprevalence of C. burnetii Abs in this study was $31.5 \%$ which is nearly the same $(30.7 \%)$ as reported by Jarelnabi et al. (2018) in Saudi Arabia while disagree with the findings of Abbass et al. (2020) who reported 45.3\% seroprevalence in cattle may be due to different period. Also disagree with Johnson et al. (2019) who reported $21.7 \%$ seroprevalence in cattle in Ghana. IgG seroprevalence was significantly higher in serum $25.5 \%$ than in milk $14.2 \%$. In addition, within serum, $\operatorname{IgG}(25.5 \%)$ was significantly higher than IgM $(12.1 \%)$. IgG results agree with the findings of Elhofy et al. (2020) who reported, $\mathrm{IgG}$ seroprevalence $24 \%$ in sera and $10.6 \%$ in milk. In this study, no significant difference was observed between positive $\operatorname{IgM}$ in serum and milk; 12.1 and $10.6 \%$, respectively. Also Elhofy et al- (2020) reported no significant difference between $\operatorname{IgM}$ in sera $(7.3 \%)$ and milk $(6 \%)$. Significantly higher $\operatorname{IgG}$ over $\operatorname{IgM}$, in this study, in serum and milk agree with the findings of Cekani et al- (2008) and Khalifa et al. (2016). Seroprevalence at Governorates ranged from 30 to $37.3 \%$ in cows and from 17.9 to $18.2 \%$ in buffaloes, disagree with the findings of Klemmer et al. (2018) who recorded 4.2 to $36.4 \%$ seroprevalence in cattle and 3.3 to $100 \%$ in buffaloes. This difference could be due to difference in geographical scope or time and season. The highest IgG seroprevalence was observed in Beni-swif with $24.5 \%$ followed by Minya with $23.9 \%$ then Assuit, Giza, Dakahlya and Fayoum with 21.7, 21.2, 19.4 and 15.2\%, respectivly. The highest IgM seroprevalence was observed in Dakahlya $13.9 \%$ followed by Giza, Fayoum, Beni-swif, Assuit and Minya with 12.9, 11.6, 10, 10 and 6.5\%, respectivly, which is comparable to the findings of Elhofy et al. (2020) where the highest IgG was in Giza (30\%) followed by Beni-Swif and Fayoum with 24 and 20\%, respectively. We both agreed in the seroprevalence of Beni-swif and Fayoum having the lowest seroprevalence. However, in our study, Beni-swif has the highest IgG seroprevalence. Our results differ again from the findings of Elhofy et al. (2020) who reported the highest IgM in Fayoum and Beni-swif (8\%) followed by Giza (5\%). No significant difference was found between Governorates in IgG or IgM neither in serum nor in milk. However, within Governorates, significantly higher seropositive IgG over IgM was observed in Assuit, Beni-Swif and Minya with $21.7,24.5$ and $23.9 \%$, respectively. These results confirm $\mathrm{Q}$ fever is endemic throughout Egypt in ruminants as proposed by Klemmer et al. (2018).

In relation to animal species, total seroprevalence in cows $(20.9 \%)$ was higher than in buffaloes $(12 \%)$, which is in accordance with the findings of Klemmer et al.
(2018) who reported 19.3 and $11.2 \%$ in cows and buffaloes, respectively. Lower seroprevalence in buffaloes than cows may be due to lower susceptibility Nahed and Khaled (2012). Our results disagree with the findings of Gwida et al. (2020) who reported C. burnetii Abs $20.8 \%$ in buffalo and $16 \%$ in cattle. This difference could be attributed to different sample source and different serological test (ELISA), only animals with history of abortion. In this study, the general serum profile of IgG seroprevalence was replicated in cows' serum. IgG seroprevalence of cows was significantly higher in serum (26\%) than milk (14.8\%). In addition, within serum, seropositive $\operatorname{IgG}(26 \%)$ was significantly higher than seropositive IgM (12.5\%). Klemmer et al. (2018) pointed that animal species and geographical location are potential risks associated with seropositive $C$. burnetii.

C. burnetii infection in ruminants is primarily characterized by reproductive disorders such as abortion, stillbirth, endometritis, mastitis, and infertility (Lang 1990; To et al. 1998). In this study, seroprevalence of anti-Coxiella IgG and IgM between and within different reproductive status of buffaloes and cows were estimated. Between different reproductive status, in cows, both $\mathrm{IgG}$ and IgM were significantly the highest in abortion. Also, IgG seropositive was significantly higher in repeat breeder than apparent healthy. For buffaloes, only IgM seropositive was significantly the highest in abortion. Within reproductive status, in cows' sera, significant higher IgG seropositive over IgM was observed in all reproductive status. While in cows' milk samples, only abortion showed significant higher IgG seropositive over IgM. In buffaloes, no significance was observed between seropositive $\mathrm{IgG}$ and $\mathrm{IgM}$ neither in sera nor in milk samples. This study revealed significant higher seroprevalence of anti-Coxiella Abs in cow serum and milk samples with reproductive problems specially abortion, either between or within, than apparent healthy animals. These results agree with the findings of Agerholm (2013), Hansen et al. (2011) and Scolamacchia et al. (2010) who stated that $C$. burnetii infection has been associated with bovine abortion, premature delivery and birth of weak neonates in dairy cattle. However, our results also disagree with the findings of Ruiz-Fons et al (2010) and Kim et al. (2006) who observed no correlation between abortion and seroprevalence in domestic ruminants.

A total of $8(4.2 \%)$ seropositive serum and milk samples were found PCR positive for $C$. burnetii using qPCR. The icd gene of $C$.burnetii was detected only in 6 milk samples $(8.6 \%)$ and 2 sera samples $(1.7 \%)$. These results agree with the findings of Kirkan et al. (2008), who recorded $4.3 \%$ in cattle serum and with To et al. (1998) who reported $3.9 \%$ in Japan. And nearly in line with the findings of Yadav et al. (2021) who reported positive $6.87 \%$ of milk and $1.55 \%$ sera samples from cattle using TaqMan real-time PCR.

\section{Conclusion}

In this study, IgG in serum was significantly higher between and/or within sample types, Governorates, species and animal reproductive status. The findings recommend the use of $\mathrm{IgG} \mathrm{Ab}$ against $C$. burnetii to provide evidence of past contact (Natale et al. 2012). In 
addition, we confirmed IFA is suitable for detection of $C$. burnetii prevalence in cattle and buffaloes that help in identifying risk factors in C. burnetii epidemiology.

\section{Acknowledgment}

This paper is based upon work supported by Animal Reproduction Research Institute, ARC, Egypt and FLI, Germany. The authors would like to thank Professors Hosney Eladawy, Cathia Martien, and H. Neubor for their technical help.

\section{Authors' Contributions}

HFM Mo'awad collected the samples, performed the practical part, data analysis, interpretation and writing the original draft. MM Sobhy supervised the study. TF Ismail analyzed the data, edited and reviewed the paper. M ElElenbaawy organized of the whole paper in final form. All authors read and approved the final version of manuscript.

\section{REFERENCES}

Abbass H, Selim SAK, Sobhy MM, El-Mokhtar MA, Elhariri M and Abd-Elhafeez HH, 2020. High prevalence of Coxiella burnetii infection in humans and livestock in Assiut, Egypt: A serological and molecular survey. Veterinary World 13: 2578-2586. https://doi.rg/10.14202/vetworld2020.2578-2586

Agerholm JS, 2013. Coxiella burnetii associated reproductive disorders in domestic animals a critical review. Acta Veteriniria Scandinavica 55: 13. https://doi.org/10.1186/ 1751-0147-55-13

Angen Ø, Ståhl M, Agerholm JS, Christoffersen AB and Agger JF, 2011. Dynamics of relationship between the presence of Coxiella burnetii DNA, antibodies, and intrinsic variables in cow milk and bulk tank milk from Danish dairy cattle. Dairy Science 94: 5750-5759. https://doi.org/ 10.3168/jds.2011-4197

Carbonero A, Guzman LT, Montano K, Torralbo A, ArenasMontes A and Saa LR, 2015. Coxiella burnetii seroprevalence and associated risk factors in dairy and mixed cattle farms from Ecuador. Preventive Veterinary Medicine 118: 427-435. https://doi.org/10.1016/j. prevetmed.2015.01.007

Cekani M, Papa A, Kota M, Velo E and Berxholi K, 2008. Report of a serological study of Coxiella burnetii in domestic animals in Albania. Veterinary Journal 175: 276278. https://doi.org/10.3923/ajava.2009.114.121

Chochlakis D, Santos AS, Giadinis ND, Papadopoulos D, Boubaris L, Kalaitzakis E, Psaroulaki A, Kritas SK and Petridou EI, 2018. Genotyping of Coxiella burnetii in sheep and goat abortion samples. BMC Microbiology 18: 204. https://doi.org/10.1186/s12866 018-1353-y

Centers for Disease Control and Prevention. Diagnosis and Management of Q fever, Recommendations from CDC and the Q Fever Working Group. The Morbidity and Mortality Weekly Report 2013. 62: 9-10.

Eldin C, Melenotte C, Mediannikov O, Ghigo E, Million M, Edouard S, Mege JL, Maurin M and Raoult D, 2017. From Q Fever to Coxiella burnetii Infection: a Paradigm change. Clinical Microbiology Review 30: 115-190. https://doi.org/ 10.1128/CMR.00045-16

Elhofy FI, Hassaballa MS and Abd El Tawab A, 2020. Seroprevalence detection of Coxiella burnetii antibodies in milk and serum of dairy cattle by recent methods. Benha Veterinary Medical Journal 38: 57-60.

Gürtler L, Bauerfeind U, Blümel J, Burger R, Drosten C, Gröner A, Heiden M, Hildebrandt M, Jansen B, Offergeld R, Pauli G, Seitz R, Schlenkrich U, Schottstedt V, Strobel J and Willkommen H, 2014. Coxiella burnetii pathogenic agent of $\mathrm{Q}$ fever. Transfus Medical Hemother 41: 60-72. https://doi.org/10.1159/000357107

Gwida M, El-Ashker M, Awad A, Khan I and El Gohary A, 2020. Seroprevalence of Brucellosis and Coxiellosis in a Linked Study Population in Egypt. Asian Journal of Research in Animal and Veterinary Sciences 6: 33-40.

Hansen MS, Rodolakis A, Cochonneau D, Agger JF, Christoffersen AB, Jensen TK, et al. 2011. Coxiella burnetii associated placental lesions and infection level in parturient cows. Veterinary journal 190: e135-9. https://doi.org/10.1016/j.tvj1.2010.12.021

Jarelnabi AA, Alshaikh MA, Bakhiet AO, Omer SA, Aljumaah RS, Harkiss GD, Mohammed OB and Hussein MF, 2018. Seroprevalence of Q fever in farm animals in Saudi Arabia. Biomedical Research 29: 895-900. https://doi.org/10.4066 /biomedicalresearch. 29-17-770

Johnson SA, Kaneene JB, Asare-Dompreh K, TasiameW, Mensah IG, Afakye K, Simpson SV and Addo K, 2019. Seroprevalence of Q fever in cattle, sheep and goats in the Volta region of Ghana. Veterinary Medicine Science 5: 402-411. https://doi.org/10.1002/vms3.160

Kim WJ, Hahn TW, Kim DY, Lee MG, Jung KS, Ogawa M, Kishimoto T, Lee ME and Lee SJ, 2006. Seroprevalence of Coxiella burnetii Infection in dairy cattle and non symptomatic people for routine health screening in Korea. Korean Medical Scince 2: 823-826. https://doi.org/ 10.3346/jkms.2006.21.5.823

Kirkan S, Kaya O, Tekbiyik S and Parin U, 2008. Detection of Coxiella burnetii in cattle by PCR Turk. Veterinary Animal Science 32: 215-220.

Klemmer J, Njeru J, Emam A, El-Sayed A, Moawad AA, Henning K, Elbeskawy MA, Sauter-Louis C, Straubinger RK, Neubauer H and El-Diasty MM, 2018. Q fever in Egypt: Epidemiological survey of Coxiella burnetii specific antibodies in cattle, buffaloes, sheep, goats and camels. Public Library of Science One 13: e0192188 https://doi.org/10.1371/journal.pone.0192188

Lang GH, 1990. Coxiellosis (Q fever) in animals. In: Marrie TJ, editor. Q fever. Volume I: The Disease. CRC Press, Boca Raton, Florida, USA, pp: 23-48.

Maurin M and Raoult D. 1999. Q fever. Clinical Microbiology Review 12: 518-553.

Nahed HG, and Khaled AAM, 2012. Seroprevalence of Coxiella burnetii antibodies among farm animals and human contacts in Egypt. American Science 8: 619-621.

Khalifa NO, Elhofy FI, Fahmy HA, Sobhy MM and Agag MA, 2016. Seropervelance and molecular detection of Coxiella burnetii infection in sheep, goats and human in Egypt. ISOI, Microbiology Biotechnology Food Science 2: 1-7.

Natale A, Bucci G, Capello K, Barberio A, Tavella A, Nardelli S, Marangon S, Ceglie L, 2012. Old and new diagnostic approaches for $\mathrm{Q}$ fever diagnosis: correlation among serological (CFT, ELISA) and molecular analyses. Comparative Immunology, Microbiology and Infectious Diseases 35: 375-379. https://doi.org/10.1016/j.cimid. 2012.03.002

OIE, 2015. Terrestrial Manual Q fever Office International des Epizootics, Paris, France.

OIE, 2016. Manual of the Diagnostic Tests and Vaccines for Terrestrial Animals. Office International des Epizootics, Paris, France.

Peter SG, 2020. Zoonotic Anaplasma and Ehrlichia infections and their potential reservoirs: A review International Journal of Veterinary Science 9: 1-9.

Ruiz-Fons F, Astobiza I, Barandika JF, Hurtado A, Atxaerandio R, Juste RA and García-Pérez AL, 2010. Seroepidemiological study of $\mathrm{Q}$ fever in domestic ruminants in semiextensive grazing systems. BMC Veterinary Research 6: 13. https://doi.org/10.1186/1746-6148-6-3 
Int J Vet Sci, 2022, 11(1): 16-22.

Scolamacchia F, Handel IG, Fevre EM, Morgan KL, Tanya VN and Bronsvoort BM, 2010. Serological patterns of brucellosis, leptospirosis and Q fever in Bos indicus cattle in Cameroon. Public Library of Science One 5: e8623. https://doi.org/10.1371/journal.pone.0008623

Setiyono A, Ogawa M, Cai Y, Shiga S, Kishimoto T, Kurane I, 2005. New criteria for immunofluorescence assay for Q fever diagnosis in Japan. Clinical Microbiology 43: 55555559. https://dx.doi.org/10.1128\%2FJCM.43.11.55555559. 2005

Sherry A. M. Johnson, John B. Kaneene, Kweku AsareDompreh, William Tasiame, Ivy G. Mensah, Kofi Afakye, Shirley V. Simpson and Kwasi Addo, 2019. Seroprevalence of Q fever in cattle, sheep and goats in the Volta region of Ghana. Veterinary Medicine and Science 5: 402-411. https://dx.doi.org/10.1002/vms3.160

To H, Sakai R, Shirota K, Kano C, Abe S, Sugimoto T, Takehara K, Morita C, Takashima I, Maruyama T, et al. 1998. Coxiellosis in domestic and wild birds from Japan. Wild life Diseases 34: 310-316.

Vaidya VM, Malik SV, Kaur S, Kumar S and Barbuddhe SB, 2008. Comparison of PCR, immunofluorescence assay and pathogen isolation for diagnosis of $\mathrm{q}$ fever in humans with spontaneous abortions. Clininical Microbiology 46: 20382044. https://dx.doi.org/10.1128\%2FJCM.01874-07

Van Leuken JPG, Swart AN, Brandsma J, Terink W, Van de Kassteele J, Droogers P, Sauter F, Havelaar AH and Van der Hoek W, 2016. Human Q fever incidence is associated to spatiotemporal environmental conditions. One Health 2: 77-87. https://doi.org/10.1016/j.onehlt.2016.03.004

Yadav JP, Malik SVS, Dhaka P, Kumar A, Kumar M, Bhoomika S, Gourkhede D, Singh RV, Barbuddhe SB and Rawool DB, 2021. Coxiella burnetii in cattle and their human contacts in a gaushala (cattle shelter) from India and its partial com 1 gene sequence-based phylogenetic analysis. Animal Biotechnology https://doi.org/10.1080/10495398.2021.1906264

Wegdam-Blans MCA, Wielders CCH, Meekelenkamp J, Korbeeck JM, Herremans T, Tjhie HT, Bijlmer HA, Koopmans MPG and Schneeberger PM, 2012. Evaluation of commonly used serological tests for detection of Coxiella burnetii antibodies in well-defined acute and follow-up sera. Clinical Vaccine Immunology 19: 1110. https://doi.org/10.1128/CVI. 05581-11 